Что касается написания названия демона с прописной буквы, то оно, видимо, обусловлено влиянием сложившейся еще в «мифологических» сочинениях XVIII в. традиции писать таким образом названия демонов - это объяснимо стремлением поставить леших, домовых и т. п. в один ряд с языческими богами.

Власова М. Н. Русские суеверия : энцикл. словарь. СПб., 1998.

Георгиевский А. Народная демонология // Олонецкий сборник: Материалы для истории, географии, статистики и этнографии Олонецкого края. Вып. 4. Петрозаводск, 1902. С. 53-61.

Конкка А. П. Святке - мифологический персонаж зимних Святок на востоке Олонецкой губернии и его карельские параллели // Уникальное и типичное в славянском фольклоре / отв. ред. А. Б. Мороз. М., 2018. В печати.

DOI 10.31168/7996-2700-3.80

\author{
И. И. Муллонен*, Е. В. Захарова** \\ Петрозаводск, Россия \\ *mullonen@sampo.ru \\ **katja.zaharova@mail.ru
}

Институт языка, литературы и истории КарНЦ РАН

\title{
Проблемы интеграции прибалтийско-финских топонимов в официальное русское употребление*
}

Прикладная топонимика призвана решать насущные практические задачи, устанавливающие нормы орфографии, орфоэпии, образования грамматических форм топонимов, имеющих официальное бытование. Вопросы стандартизации стоят особенно актуально в национальных регионах России, где решается задача интеграции национальных топонимов в официальное русское употребление.

В Карелии, благодаря многовековому взаимодействию прибалтийско-финской и русской топосистем, сложились многие естественные нормы, образцы адаптации карельской / вепсской топонимии

\footnotetext{
* Публикация подготовлена в рамках выполнения проекта РФФИ № 19-012-00068А «Ойконимическая система южной Карелии: на стыке традиций и инноваций».
}

(С) Муллонен И. И., Захарова Е. В., 2019 
в русское языковое пространство [см., например: Муллонен, 2002; Захарова, 2015]. Вместе с тем языковая практика ставит новые задачи, вызванные как меняющимся социокультурным контекстом, так и тем обстоятельством, что адаптация - это процесс, и в этом процессе топоним не статичен. Так, еще пару десятилетий назад название острова Кижи и расположенного на нем музея-заповедника произносилось с ударением на второй слог (Кижи́), по общерусской норме, однако ставка на местную идентичность привела к возвращению на официальный уровень традиционной заонежской нормы Ки́жи. При этом, будучи уже давно интегрированным в русское языковое бытование, топоним склоняется по нормам существительного мн. ч. (Ки́жи : в Ки́жах), в то время как название районного центра Ло́ухи, идентичное по структуре, но еще не в полной мере «обкатанное» русским языком, не склоняется (или склоняется окказионально в речи неместного населения).

Традиционная для субстратных топонимов русской Карелии ударность первого слога (г. Ко́ндопога, оз. Ся́ргозеро) размыта в северных и западных районах республики (г. Сортава́ла, оз. Ледмо́зеро). Причиной является массовый приток туда в послевоенное время населения из-за пределов республики, не усвоившего региональную модель, которая сложилась исторически, в ходе постепенного обрусения через этап двуязычия местных карелов и вепсов. Научное сообщество (в нашем случае ономастический центр ИЯЛИ) отслеживает ситуацию и предлагает решение по нормированию и унификации ударения, а также словоизменения с учетом как языковых норм, так и местной традиции.

Значительно сложнее - в плане организационном - решаются проблемы правописания топонимов. Оно регламентируется такой системой, как Государственный каталог географических названий, внесению в который подлежат наименования географических объектов РФ. Работы по созданию и ведению каталога осуществляет Федеральная служба государственной регистрации, кадастра и картографии (Росреестр). Реестр зарегистрированных по Республике Карелия географических названий включает около 16000 топонимов - наименований населенных пунктов, объектов гидрографии и орографии. Их анализ наглядно свидетельствует о значительных сложностях орфографического порядка, возникающих при русской передаче таких специфических особенностей прибалтийско-финских топонимов, как геминированные 
согласные, долгие гласные, дифтонги, гласные переднего ряда $y, \ddot{a}, \ddot{o}$, сочетание «j + гласный» и др. В передаче названий с такими фонетическими чертами нет последовательности. Например, детерминант -joki 'река' в одних случаях передается транскрипцией (Курки/ёки), в других — транслитерацией (Хейня/йоки); не выдерживается долгота гласных (варианты -вара и -ваара при исходном -vaаra 'гора'); карельское $y$ передается как русское ю, у или $u$ (Юлюламби $\leftarrow$ Ylälambi «Верхняя ламба»; Улеламби $\leftarrow$ Ylälambi; Иляйоки $\leftarrow$ Yläjoki «Верхняя река»).

Принципиально важно то, что эта «разноголосица» закреплена официально. В соответствии с Федеральным законом № 152 от 18.12.1997 «О наименованиях географических объектов» именно государственным каталогом определяется написание топонимов во всех официальных ситуациях: в документах, на дорожных указателях, картах, в разного рода справочниках и т. д., а отступление от него считается административным правонарушением. Это усугубляется тем, что, помимо отмеченной непоследовательности, в каталог закрались и явные ошибки.

Наши предварительные подсчеты свидетельствуют о том, что ошибочное написание отмечается примерно в 7-10\% топонимов карельского реестра. Основная часть их связана с передачей специфических прибалтийско-финских особенностей, но есть и обычные описки: руч. Кайноважоя учтен как Кайноваркоя, а ур. Харакковаара «Сорочья гора» превратилось в Каракговара. Будучи официально закрепленными, топонимы из списка Росреестра, в том числе и ошибочные, обязательны для употребления. В результате, например, обновление дорожных указателей привело к появлению таких топонимических «новоделов», как р. Колос вместо традиционного Коллас (из карел. Kollas) или р. Горная вместо прежнего Гознея (из вепс. Нozn'oja «Хвощовый ручей»), в соответствии с ошибочным написанием в реестре. При этом все попытки и местных жителей, и научного сообщества внести правку пока не привели к успеху.

Между тем канонический список Росреестра оказывается своего рода «миной замедленного действия», поскольку заложенные в нем ошибки и опечатки воспроизводятся при включении объекта в активное использование. Так случилось с названием старинного приладожского поселения Кавайно (ист. Кавандо: kaivando (gen. kaivanno-n) 'выкопанная канава; перекоп'), которое в 2001 г. в связи с восстановлением 
статуса населенного пункта было официально изменено на ошибочное Ковайно на основании неверной записи в реестре. Развитие туризма активизирует использование гидронимии, и в результате подобные ошибки не только «перекочевывают» на карты и в атласы, но и воспроизводятся в названиях гостевых домов, кемпингов и т. д.

Для исправления ситуации на первом этапе необходимо в сотрудничестве со службой Росреестра внести правку в ошибочные написания, а в дальнейшем по возможности унифицировать каждое написание в случае «разнобоя».

Захарова E. B. Интеграция субстратных прибалтийско-финских топонимов в русскую топосистему Восточного Обонежья : дис. ... канд. филол. наук / ИЯЛИ КарНЦ РАН. Петрозаводск, 2015.

Муллонен И. И. Топонимия Присвирья: Проблемы этноязыкового контактирования. Петрозаводск, 2002.

DOI $10.31168 / 7996-2700-3.81$

\author{
С. А. Мызников \\ Институт славяноведения РАН \\ Москва, Россия \\ myznikovs@rambler.ru
}

Славянская лексика

в этимологических словарях финского языка: опыт критического анализа

Прибалтийско-финская этимологическая лексикография имеет значительные достижения. К настоящему времени изданы весьма основательные словари: «Suomen kielen etymologinen sanakirja» [SKES] и «Suomen sanojen alkuperä. Etymologinen sanakirja» [SSA].

В индексе первого из названных словарей представлены следующие славянские языки: белорусский, болгарский, полабский, польский, русский, серболужицкий, сербохорватский, словенский, старославянский, украинский и чешский. При этом славянские лексемы фигурируют не только в тех случаях, когда они являются заимствованиями, но (C) Мызников С. А., 2019 